\title{
Implementation of Project Based Learning Model for Anti Corruption Subject in Fundamental Training for BPKP's Civil Servant Candidates of the Millennials Generation
}

\author{
${ }^{1 \text { st }}$ Mustofa Kamal \\ Pusdiklatwas BPKP, Pandansari, Ciawi, \\ Bogor, 16720 \\ kamalopek@gmail.com
}

\author{
2nd John Elim \\ Pusdiklatwas BPKP, Pandansari, Ciawi, Bogor 16720 \\ and Persada Indonesia University, YAI, Jakarta \\ elimjohn@yahoo.com
}

\begin{abstract}
Anti corruption subject for civil servant candidats in the fundamental training must be done effectively. The learning objective is the trainees can be able to show and act the anti corruption values (attitude and behavior) during the training period. To achieve it, the anti corruption learning process should be considered of the characters of the millennials generation of civil servant candidates. Method used in the research is the action research that uses trainees' reflection who get involved in activities at certain situation with aim to improve in all aspects. The project based learning model can be implemented through project assignment such as creating songs and mini stories of anti corruption's video clip. The assessment of the model implementation involves 32 trainees of the " $C$ " class of civil servant candidates' fundamental training as a sample. The action research result indicates that actualization process of anti corruption attitude and behavior of those trainees have been done conveniently, interactively, usefully and effectively in supporting anti corruption understandings.
\end{abstract}

Keywords - anti corruption, action research, project based learning; attitude and behavior

\section{BACKGROUND}

Civil servant competencies consist of technical, managerial and social cultural competencies (Number 5 of Indonesian Act of 2014 concerning State Civil Servant). Their competencies need to be developed through highly quality training (Suharsono, [15]) in order to become a high character and professional civil servant. One way to get it, the civil servant candidates have obligation to join a fundamental training with certain curriculum designed by the Indonesian State Administrative Board (Number 24 of State Administrative Board Regulation of 2017 [13]).
The curriculum of fundamental training for second level of civil servant candidates consists of forming characters and strengthening technical competency for a certain field of assignment. A part of curriculum for forming civil servant candidate character is agenda for fundamental values of civil servant candidate that consists of Accountability, Nationalism, Public Ethics, Quality Commitment, and Anti Corruption. The objective of the anti corruption learning is trainees can be able to actualize their attitudes and behaviors of trusty and honest and can prevent or prohibit any corruptive actions in their environment (Number 24 of State Administrative Board Regulation of 2017 [13]). To achieve the objective, learning of anti corruption subject for the second level of civil servant candidates of 2018 in the Education and Tranining Center (Pusdiklatwas) of Supervisory for Finance and Development Agency (Badan Pengawasan Keuangan dan Pembangunan/BPKP) use anti corruption module with training methodology such as reading, demonstrating anti corruption actions, reflecting, discussing, simulating, watching a short film, group discussing, playing role model. At the end of the learning, there are internalisasing of anti corruption value result as an embryo in actualizating the value at their workplaces (Anti Corruption Module [17]).

From the point of view of the trainees, trainer should realize that the civil servant candidates were born in around 1996 and they are categorized as millennials generation. The generation tends do not care of social condition around them. Majority of the generation cares only on boasting the pattern of freedom, hedonism, having unrealistic vision, not to having idealistic, and the important point are having style appearance and capable of high technology. 
They have not been conscious of their futures (Millennials [10]).

Based on the explanation above, reseachers agree to use a learning model developed that is fitting with the nature or characteristics of millennials generation in order to achieve the effective learnings. The reseachers propose to use project-based learning model. Fikriyah et.al. [3] in their research proved that the use of project-based learning with audiovisual media has no significant effect on students' physics learning outcomes in the science skill process at Number 4 of State High School in Jember, West Java. However, Nurfitriyanti [11] proved that the application of project based learning model have an effect on improving students' ability in solving math problem at private vocational high school in East Bekasi. Pratama and Prastyaningrum [12] also proved that the application of project based learning model of learning media of microhydro power generation can improve the critical thinking ability of students in the subject of physics engineering course at IKIP PGRI in Madiun. Several previous studies have done in school or formal education area. While the use of project based learning model in this research will be applied in basic training of civil servant candidate. Therefore the research question is "How to implement project-based learning model for anti corruption learning subject for the civil servant candidates?" and the second question is "How effective project-based learning model implementation in anti corruption learning subject of BPKP's civil servant candidates?"

The objectives of the research are firstly, to evaluate the practice of the project-based learning model in anti corruption subject and secondly, to assess the effectiveness of the project-based learning model in anti corruption subject implementation. The results of the research will be expected to be useful for the formation of anti corruption attitude and behavior of civil servant candidates, development of fundamental values learning method for civil servant candidates, and development of action research for implementing the model in the class of the fundamental learning for civil servant candidates.

\section{THEORETICAL REVIEW}

\subsection{Millennial Generation}

Millennials or Y generation are group of people who were born after $\mathrm{X}$ generation, that is generation who were born around 1980-2000. Millennials are categorized special because the generation is totally different from the previous generation, especially concerning with technology. That is why the generation is sophisticated with technology. Indonesia population is recorded approximately 255 millions people. 81 millions of that are millennials generation that aged around 17-37 years old. The millennials has high ability in 'technology world' and its infrastructure. However, they still not yet realize for their chance or opportunity in the future.

There are some aspects that should be pushed for millennials generation in order to direct their attitude and behavior for beneficial to the nation. There are as follows.

1) Critical thinking.

Millennials generation are necessary to be motivated not to 'swallow unripe' information they get. They should be invited to think critically and motivate to contribute valuable ideas in making decision of problems around them.

2) Use social media wisely

Social media can be like a double-edged sword that depends on how they use it. Therefore, they should not be banned using social media, otherwise they should be directed.

3) Ideas creating

Millennials generation should be challanged to create ideas because idea is cheap. They should be invited to discuss interesting ideas and plan how to implement it to achive the objectives (Millennials, [10]).

\subsection{Project-Based Learning Model}

Training model is a conceptual framework that describes systematic procedures in organizing learning experience to achieve certain training objectives. Training model has function as a guidance for the learning designers and teachers or trainers in planning of learn and learning activities (Sagala, 2005 in Suryadi and Pramudia [16]). There are some adult learning models, that are experiental learning, cooperative learning, collaborative learning, selfdirected learning, and project-based learning (Suryadi and Pramudia [16]).

Project-based learning model is a learning model proposed by John Dewey concerning "learning by doing" concept that is a process of learning result by doing certain activities in line with the objective (Grant, 2002 in Suryadi and Pramudia, [16]). This model can be used as a learning model to develop students' ability to plan, communicate, solve problems and make informed decisions (Nurfitriyanti, [11]).

In this model, trainees are also required to explore, assess, interpret, synthesize, and produce information in different forms of learning outcomes. Educators only act as facilitators (Pratama and Prastyaningrum [12]). Trainees are divided in groups to complete the 
interesting project and are selected by the trainees themselves (Suryadi and Pramudia, [16]).

By getting them involve in completing the project, the trainees can find problem that must be solved with objective to build and show the product end as a response of question. There are three constructivism principles in implementing project-based learning model: learning based on specific contexts, trainees get involve actively and trainees achieve what they want to get through social interactions and sharing knowledge and experience.

\subsection{Attitude and Behavior Change}

In anti corruption subject of fundamental learning for civil servant candidates, there are 3 (three) attitude and behavior changes objectives: willingness, identification, and internalisation of fundamental anti corruption values. The willingness of integrity (integrity compliance) will take place when the trainees are willing to accept the influence of integrity from other people or from other groups because they expect to receive positive reactions from the others. The second objective is the identification of integrity. Identification of integrity can be indicated by an attitude decision that will be expected other party will do the same decision. The integrity of individuals will be in line not only with group expectation but also in line with his or her roles in social relationship in the group.

The third objective is internatilization of fundamental anti corruption values. Internalization is the highest permanent attitude and behavior changes. Internalization of integrity takes place when individuals accept the integrity influence and are willing to act the integrity attitude and behavior because the integirty is the value they trust and in line with his or her value system. Intenalization of integrity is related tighly with value, belief, culture, and self concept aspects in human subconscious (Kelman, 1958; Brigham, 1991 in Anti Corruption Commission Module [17]).

\subsection{Action Research}

Action research is a method used in social field research that uses trainee reflection who gets involved in activites at certain situation with aim to improve in all aspects. Action research is different from empirical research. Identification of population and sample taken and generalization (as an one of the main characteristics in empirical research) are not a problem in action research.

The research focuses on giving recommendation in solving the problem (Module of LAN, [18]).The action research has 2 (two) objectives. First, to improve and second, to involve. To improve means improvement in practical field, improvement of practical understandings done by pratitioners and improvement of condition of location where learning takes place. To involve means involvement of those parties (Grundy and Kemmis, 1990; 322 in idthesis, [4]).

\section{RESEARCH METHODOLOGY}

The research is a qualitative research using action research methodology with procedures; planning, action taken, oberservation and reflection (H.P.Ahmad [5]).

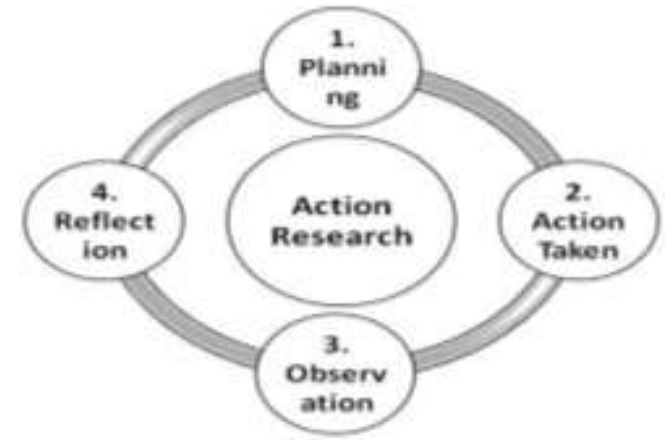

Fig. 1 Action Reserach

Figure 1 shows that action research is a cycle. It starts from planning and the end is reflection that will be considered a recommendation to develop for the following further research.

Research objects are the 32 trainees of civil servant candidates in the fundamental learning for BPKP's "C" class in Pusdiklatwas. A variety of learning methods was applied. However, researchers limit the research on main model used, project-based learning method. The model used considers the characteristics or characters of the trainees as millennial generation and they have already got the anti corruption subject when they took their bachelor degree in the State Finance Polytechnic. There are 4 (four) evaluation steps in measuring the research purpose. Firstly, the project done by the trainees, secondly, the presentation of the projects, thirdly, assessment of the presentation by trainer and trainees from other groups, and the fourthly, observation by the trainer as a whole.

The trainee actions are observed in undertaking project assignments. Observation aspects are changing of attitude and behavior through three social change processes: willingness, identification and internalization (Kelman, 1958 and Brigham, 1991 in Anti Corruption Commission Module [17]). The research steps as follows. 


\section{TABLE I STEPS OF ACTION RESEARCH}

\begin{tabular}{|c|c|}
\hline STEPS & IMPLEMENTATION \\
\hline Planning & $\begin{array}{ll}\text { 1. } & \text { Assignment submission; project will be } \\
\text { undertaken by trainees } \\
\text { 2. Grouping } \\
\text { 3. }\end{array}$ \\
\hline Action & $\begin{array}{ll}\text { 4. Undertaking a project assignment in } \\
\text { 5. location } \\
\text { 6. Information of project assignment } \\
\text { 7. } \\
\text { assessment } \\
\text { Presentation of project result } \\
\text { Assessment of the presentation } \\
\end{array}$ \\
\hline Observation & $\begin{array}{l}\text { Advantages of high level project } \\
\text { Observation of anti corruption attitude and } \\
\text { behavior change }\end{array}$ \\
\hline Reflection & $\begin{array}{l}\text { 10. Learning effectiveness } \\
\text { 11. Opini and recommendation to improve } \\
\text { learning }\end{array}$ \\
\hline
\end{tabular}

\section{RESEARCH RESULT AND EXPLANATION}

\subsection{Planning}

Trainees have a project assignment in groups in form of 'song/fragment anti corruption video clip'. The assignment undertaken by using smart phone (gadget) with shooting location in Pusdiklatwas. Trainees were divided into 5 groups with six or seven people in each group.

TABLE II SONG/FRAGMENT ANTI CORRUPTION PROJECT GROUP

\begin{tabular}{|c|c|c|}
\hline & TOTAL & NAME OF MEMBER \\
\hline I & 6 & $\begin{array}{l}\text { Maulana Elen Yudha Shugara (M), } \\
\text { Muhammad Juniardo (M), Mohammad } \\
\text { Rifqi Hidayatullah (M), Muhammad Al } \\
\text { Kahfi (M), Ricval Mawardi (M), Wita } \\
\text { Rosmalia Siahaan (F). }\end{array}$ \\
\hline II & 7 & $\begin{array}{l}\text { M. Ishak Arofik (M), Mohammad Kenigi } \\
\text { Harisandi (M), Muchammad Nurul Huda } \\
\text { (M), Maraya Ghifara (F), Ribka Esti } \\
\text { Prantiasih (F), Rizki Dita Ramadani (F), } \\
\text { Nuhammad Nafisya (M). }\end{array}$ \\
\hline III & 7 & $\begin{array}{l}\text { M. Sobri Qomarudin (M), Maria Endah } \\
\text { Saraswati (F), Mauritzky Hasiholan } \\
\text { Napitupulu (M), Muhammad Ridwanullah } \\
\text { (M), Muhammad Khaidir Arief (M), Riris } \\
\text { Purnalita (F), Saarah Khansaria Khairunnisa } \\
\text { (F). }\end{array}$ \\
\hline IV & 6 & $\begin{array}{l}\text { Adib Muhammad Iyasy (M), M. Hafiz (M), } \\
\text { M. Faisal Ghifari (M), M. Farhan Fauzan } \\
\text { (M), M. Hardanu Hermawan (M), Rizky } \\
\text { Amalia Putri (F). }\end{array}$ \\
\hline $\mathrm{V}$ & 6 & $\begin{array}{l}\text { M. Indra Arief Lubis (M), Muhammad Bayu } \\
\text { Riyadi (M), Muhammad Faisal Izzudin Al- } \\
\text { Qossam (M), Muhammad Habibi Pasi (M), } \\
\text { Risan Adhitama (M), Riska Kurnia } \\
\text { Maghfiroh (F). }\end{array}$ \\
\hline & & \\
\hline
\end{tabular}

The next step, trainer informs the anti corruption song/fragment video clip rules as follows.

- Song/fragment chosen is based on group discussion.

All members of group must be involved and exist in video clip.

- The video clip project assignment is done on Sunday.

- All members must be collaborated through distribution of roles and duties.

- Determination of shooting location and all infrastructure.

Actualization of recording, editing and finalizing anti corruption song/fragment video clip project.

- $\quad$ Each project assignment by a group has to be presented and subject to be assessed by the trainer and other groups.

\subsection{Action}

4.2.1 Manufacturing Process of Anti corruption Song/fragment Video Clip Project Assignment

Manufacturing process the assignment was undertaken on Sunday. Each group itself decides location in Pusdiklatwas. The group also ask for permission to the officer of Pusdiklatwas if they need room or other facilities.

The group discusses to decide the topic, song, actors, and interesting angle to be shooted. The groups provide infrastructure they need. Taking picture (shooting) is done more than once. The group observes, takes a close look and evaluate the result by themselves. Then, the group combines the result of shooting with other supporting materils such as song, animation, and other videos from youtube.The result of combination has been recorded and saved properly.

\subsubsection{Assessment of Anti Corruption Song/fragment Video Clip Assignment}

Before the group presents their results, the trainer informs the assessment procedures that consist of 4 (four) aspects: the clarity of message, the group compactness, the group seriousness, and the beauty of the result. Every aspect will be scored in three levels: 1: good enough, 2: good, and 3: very good. The assessment was done by the trainer and all members of other groups. Each trainee provides assessment documentation.

\subsubsection{Presentation of Anti Corruption Song / Fragment Video Clip Project Assignment}

The presentation of the video clip project assignment by each group was done in the class using the trainer's laptop respectively. Each group who is 
showing the video clip, takes a close look and ready to answer any question comes from the trainees from other groups. All trainees also give assessment score and ask the questions. Screenshots as parts of anti corruption song/fragment video clip project are showed as follows.

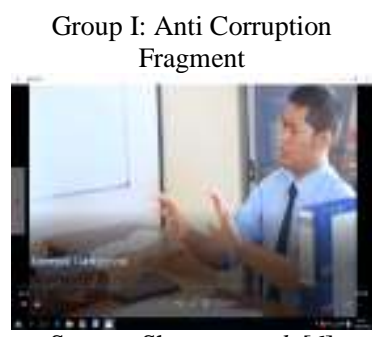

Source: Shugara et.al. [6]

Group III: "Corruption kill you”

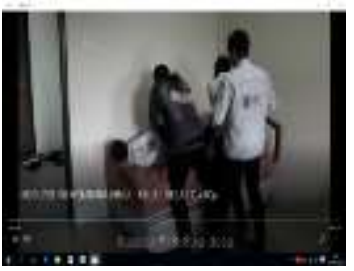

Source: Qamarudin et.al.[9]

Group V: Anti Corruption Orchestra

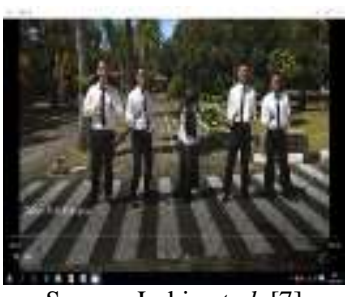

Source: Lubis et.al. [7]

Fig. 2 Anti Corruption Song/Fragment Video Clip Project Assignment for 5 Groups

\subsubsection{Assessment of Anti Corruption Song/Fragment} Video Clip Project Assignment

All groups show their project results in the class. The assessment of the project for each group can be explained as follows.

1) Anti corruption song/fragment video clip project assignment has been presented using the trainer's laptop.

2) All trainees and the trainer give score of assessment for every aspect of assessment.

3) Total score for every assessment undertaken by trainer and all trainees were be calculated.

4) Calculation of average score from total scores for each group calculation above.

5) Average score given by trainees has been combined with the score given by the trainer to get the total score.

6) Final score of each group.
The final score of each group determines which group is the best. The final score results from six groups are showed in Tabel III below.

TABLE III FINAL ASSESSMENT OF ANTI CORRUPTION SONG/FRAGMENT VIDEO CLIP PROJECT ASSESSMENT

\begin{tabular}{|c|c|c|c|c|c|c|}
\hline \multirow{2}{*}{$\begin{array}{l}\text { Asessment } \\
\text { Aspet. }\end{array}$} & \multirow{2}{*}{ Assessor } & \multicolumn{5}{|c|}{ Grougs } \\
\hline & & I & II & III & $\mathbb{N}$ & V \\
\hline \multirow{2}{*}{$\begin{array}{l}\text { Carty of } \\
\text { Message }\end{array}$} & Trainer & 3.00 & 200 & 3.00 & 200 & 203 \\
\hline & $\begin{array}{l}\text { Al leaners or stadats (cuside of } \\
\text { gow mather bity assessod) }\end{array}$ & 226 & 212 & 256 & 150 & 208 \\
\hline \multirow[b]{2}{*}{ Conprothess } & Traner & 3.00 & 200 & 3.00 & 200 & 3.02 \\
\hline & $\begin{array}{l}\text { All kanars or studats (ouside of } \\
\text { group natber being assessed) }\end{array}$ & $2 \pi$ & 236 & 276 & 200 & 265 \\
\hline \multirow[b]{2}{*}{ Strivusness } & Trainer & 3.00 & 3.00 & 3.00 & 3.00 & 3.02 \\
\hline & $\begin{array}{l}\text { All kaners or sthdats (ouside of } \\
\text { grop namber bing assessol) }\end{array}$ & 281 & 236 & 272 & 1.73 & 269 \\
\hline \multirow{4}{*}{ Bearty } & Irainer & 3.00 & 3.00 & 3.00 & 200 & 3.00 \\
\hline & $\begin{array}{l}\text { All kaners or stadats (cutside of } \\
\text { grọ namber being assessol) }\end{array}$ & 275 & 2.24 & 2.40 & 1.73 & 231 \\
\hline & TOTAL SCORE & 2259 & 19.08 & 244 & 15.96 & 20.73 \\
\hline & AVERAGE SCORE & 2.82 & 239 & 2.81 & 200 & 259 \\
\hline
\end{tabular}

From the Table 3 above, there are 2 (two) groups have high scores: Group I and Group III with final score 2.82 and 2.81 respectively.

\subsection{Observation}

\subsubsection{Advantage of High Score Project Assignment}

The result of anti corruption song/fragment video clip project was observed. Focus of the observation on the content and the presentation of two groups who are the best. Researchers interview the member of the groups and dig in dept their opinions. Anti corruption messages of the groups are so clear while the rests of groups were quite clear. Clarity aspect of the message comes from fragment of corruption practice and the impacts of corruption action.

Group I showed the fragment concisely, showing how public officer was tempted of gratification. The first time the officer rejected, however, after the amount of gratification was increased the officer cannot reject and then the officer was caughted by The Anti corruption Commision Officer. The family of the officer was sad. The same message was also showed by the group III. The song of 'corruption kills you' was played together with the scene of the officer looked enjoy with his results of corruption. He was tempted by appealing of devil and was caughted by The Anti Corruption Commission, and then the officer was put into a prison. 


\subsubsection{Observation of Attitude and Behavior Change}

Based on the observation in finishing anti corruption song/fragment video clip project assignment, the assessment can be done by looking at the changing of attitude and behavior of the trainees. The change in form of willingness, identification and internalisationing anti corruption fundamental values. The three changing process, at least, can be detected and assessed in creating, showing and assessing of the video clip session.

In creating the video clip, some trainees propose opinion and ideas in their groups. It is an indication of brave attitude which is one of anti corruption fundamental values while other trainees in the a group gave respond and accepted the opinions and ideas. They gave and received each other and got positive reactions and they hoped the result the group will be good and positive (it indicates their willingness as the first attitude and behavior change). And then, they took action bravely and responsible for their roles (as an actor/actrees, as a cameraman, a dubbing person etc) with group agreement and consensus. Those who chooses or accepts a role were eagerly hopes the successful of the group, gets better social relationships in group and their compactness. Even, at the time video clip was showing, they hope the message can be delivered better to trainees in " $C$ " class and be proven, there are questions or statements for improvement or appreciation. The condition indicates that the integrity identification (the second attitude and behavior change process) majority has been occured and exist.

The third process of the attitude and behavior change is the internalisation. The internalisation of integrity is related with value, beliefs, culture, and self concept factors that are in the subconscious order that almost a 95\% control how human being interact with their the environment (Kelman, 1958 and Brigham, 1991 in The Anti Corruption Commission Module [17]). The observation of the attitude and behavior of the fundamental learning trainees showed that the nine of anti corruption values has been applied automatically (with consciousness) in the process of creating and showing the anti corruption song/fragment video clip projects. Sequentially, the internalization of the attitude and behavior change can be explained as follows.

\section{1) Honesty}

The first fundamental values of the anti corruption is honesty. There are four of five groups $(80 \%)$ that applied the honest value with consciousness. There are three groups (I, II, and III) showed anti corruption songs/fragments in their video clips (Figure 3). While one group (Gorup V) presents honestly the names of other group members (Muhammad Farhan Fauzan and Rahma Dita Nuraeni) who have helped in creating the video clip project (Fig. 3).
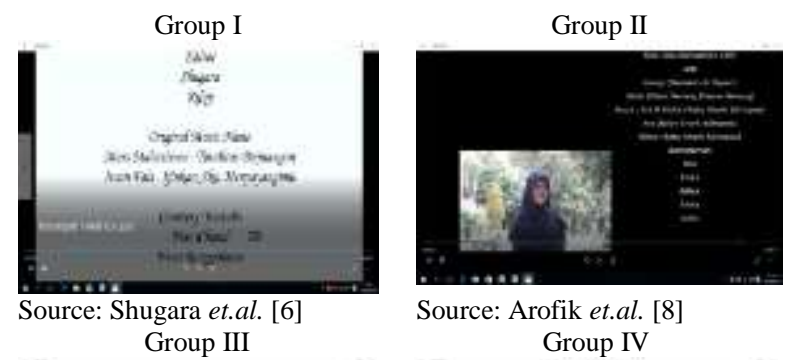

Source: Arofik et.al. [8] Group IV

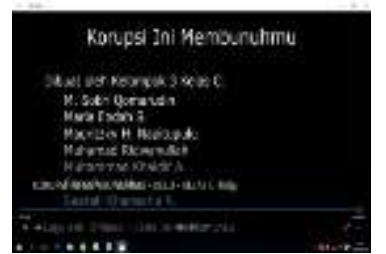

Source: Qamarudin et.al.,[9]

Fig.3 Honesty in Video Clip

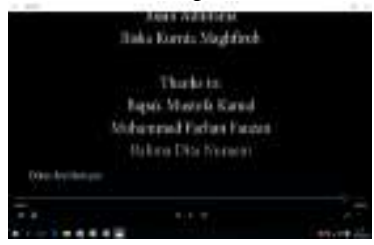

Source: Iyasy et.al. [2)

2) Care

Anti corruption fundamental value of care has been internalisated by civil servant candidates of BPKP. They supported and took care each other in a group for the same objective. They also took care of other groups who need help at the shooting time of session by presenting all member of the group (Fig. 4). There are four of five groups (80\%) (II, III, IV dan V) that was succeeded successfully in taking pictures by supporting and caring other members of groups. Their concerns each other indicate that care value was really happend and exist.
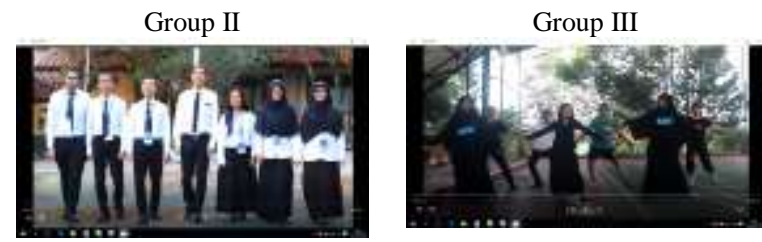

Source: Arofik et.al., 2018

Source: Qamarudin et.al., 2018
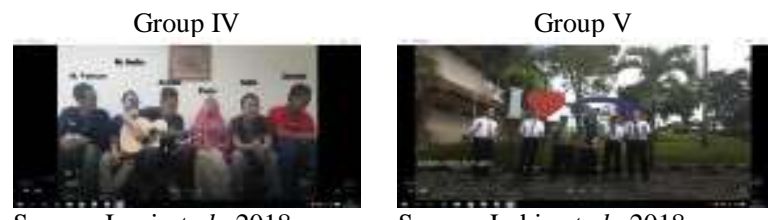

Source: Lubis et.al., 2018

Fig. 4 Care given to Other Groups

3) Independent

All groups (or 100\%) practiced and internalized an independent value when they in each group decided the theme, sharing roles, move and room organized, representative angle of location. The shooting result was processed, edited, reviewed and finalized until the anti corruption song/fragment video clip soft file was ready to submit. All the 
activities majority has done each group independently.

\section{4) Discipline}

All members of the group (or 100\%) were discipline in wearing clothes that fit with their video clips, discipline in shooting schedule, discipline in playing the role, discipline in following the rule of the project, and discipline in submitting the project to the trainer on time.

\section{5) Responsibility}

All groups (or $100 \%$ ) were responsible for their projects. The responsibility has been showed in their commitment to make a project for a learning purpose. The responsibility of group members also were showed at the time of presentation of the projects. All questions and critics arised to every group presentation has been responded and answered well. Even, there was a group who admitted honestly that their project was not good enough due to the limitation of time.

\section{6) Work Hard}

Manufacturing video clip project was done on Sunday (beyond classical learning time). In general, it took the trainees' time off. However, all trainees showed their incredible seriousness and work hard. All video clip projects have been finished completely and successfully.

\section{7) Humble}

All groups (or $100 \%$ ) behave humble. It can be seen not only from their dressed modestly and in accordance with employee clothing requirement but also their optimization of infrastructure being used.

\section{8) Brave}

All trainees in groups were displaying extraordinary courage or brave. Generally they have no enough skill and experience to be as an cameraman. However, they were brave and truly play the role in according to the demands of the scenario without fear. Just a few trainees acted awkwardly.

\section{9) Fair}

All trainees in groups shared the roles fairly. The selection of who will be a main actor and supporting actors were based on their own capabilities. Allocation of tasks like cameraman, voice over, backing vocal, files processing has been undertaken after considering of needs and capacities. The explanations above show that the roles and tasks have been done in accordance with the ability and capacity. It is fair.

\subsection{Reflection \\ 4.4.1 Learning Effectiveness of Project-Based Learning Model}

The objective of the anti corruption learning subject is that the trainees are able to actualize trust and honest attitude and behavior; and to prevent corruption act in their environment (Number 24 of State Administrative Board Regulation of 2017 [13]). From the explanation above starting from planning and action decision of the learning subject, it can be concluded that project-based learning model is effective in assessing actualization practice of anti corruption attitude and behavior (at least three days for anti corruption learning subject) in Pusdiklatwas of BPKP. Observation of anti corruption attitude and behavior in video clip project assignment has indicated that nine values of anti corruption have been done directly.

Another important point of the learning effectiveness is that there is conformity the project assignment of civil servant candidate characters who are millennials generation with the learning objective. The conformity can be showed firstly, the project assignment needs a real work collaboration, selfexpression and independent that in line with the attitude and behavior of millennials generation who tends unlike of theoretical things, like to express and like freedom. Furthermore, video clip project assignment needs high technology support such as smart phone, laptop, and internet network. Those technology in line with attitude and bahavior of millennials generation who expert in high information technology (Millennials, 2017).

\subsubsection{Recommendation for learning improvement}

Post-learning, the trainees of fundamental learning the "C" class for civil servant candidate of BPKP will be given opportunity to give on line feedback by inputing it in the google form. The trainees will expected to give opinions of the effectiveness on learning using project based learning model. They also will be given chance to propose some recommendations in order to increase and develop the anti corruption learning subject process for civil servant candidate in the future.

The feedback expected consists of the answers of two questions, firstly, According to your opinion, how good the learning process of the anti corruption subject using project based learning model is: Is it delight? Is it creative? Is it useful? Is it interactive? Is it easy to remember and/or does it support your understanding of the anti corruption subject? (More than one answer is allowed). Secondly, What is your recommendation to improve the learning process of anti corruption subject more effective in the future? 
The result of feedback taking from the google form showed 25 of 32 trainees (or 78,13\%) gave the feedback. The recaptulation of the feedback resultis shown in table 4 as follows.

\section{TABLE IV RECAPITULATION OF TRAINEE FEEDBACK} FOR PROJECT-BASED LEARNING MODEL

\begin{tabular}{|c|c|c|c|}
\hline \multicolumn{2}{|r|}{ Question I } & $\begin{array}{c}\text { Total } \\
\text { Opinions }\end{array}$ & $\begin{array}{l}\% \text { of } 25 \\
\text { Students }\end{array}$ \\
\hline \multicolumn{4}{|c|}{$\begin{array}{l}\text { According to your opinion, how } \\
\text { good the learning process of the } \\
\text { anti corruption subject using } \\
\text { project based learning model is.... }\end{array}$} \\
\hline 1. & Is it delight? & 23 & 92 \\
\hline 2. & Is it creative? & 22 & 88 \\
\hline 3. & Is it useful? & 18 & 72 \\
\hline 4. & Is it interactive? & 23 & 92 \\
\hline 5. & $\begin{array}{l}\text { Is it easy to remember and / } \\
\text { or does it support your } \\
\text { understanding of the anti } \\
\text { corruption subject? }\end{array}$ & 17 & 68 \\
\hline \multicolumn{4}{|c|}{ Question II } \\
\hline & Recommendation & $\begin{array}{c}\text { Total } \\
\text { Opinions } \\
\end{array}$ & $\begin{array}{r}\% \text { of } 25 \\
\text { Students } \\
\end{array}$ \\
\hline 1. & $\begin{array}{ll}\text { Add a corruption } & \text { case and } \\
\text { corruption } & \text { detection } \\
\text { simulation } & \\
\end{array}$ & 4 & 16 \\
\hline 2. & Add anti corruption games & 4 & 16 \\
\hline 3. & $\begin{array}{l}\text { Maintain and improve the } \\
\text { variety of learning methods }\end{array}$ & 4 & 16 \\
\hline 4. & $\begin{array}{l}\text { Explain the objectives of the } \\
\text { class assignment more detail }\end{array}$ & 1 & 4 \\
\hline 5. & $\begin{array}{l}\text { Give rewards to students } \\
\text { both marks and other goods }\end{array}$ & 1 & 4 \\
\hline 6. & $\begin{array}{l}\text { Retention test every session } \\
\text { using attractive quiz }\end{array}$ & 1 & 4 \\
\hline & Total & 15 & 60 \\
\hline
\end{tabular}

Source: Process of feedback recapitulation, Google form, 2018

Table IV for question 1 above above showed the majority of opinions agree that implementation of project-based learning model in creating a song/fragment video clip project assignment was delight, useful and it does support understanding and internalisating of anti corruption values.

Recapitulation of the second question of the students' recommendation showed that anti corruption learning subject need improvement by adding in learning method such as anti corruption games, interactive quizes, example and simulation of anti corruption cases. To make students more interested in the subject, it will be good to give rewards not only good mark but also other goods for active and enthusiastic students.

\section{CONCLUSION}

Implementation of project based learning model in the anti corruption learning subject for BPKP's civil servant candidates who are the millenials generation is effective. The model is effective in assessing the attitude and behavior change of the civil servant candidates in the anti corruption learning subject for three day training in Pusdiklatwas of BPKP. The result of this research was in line with the research result by Pratama et. al. [12] which proved that there was an effect of increasing the critical power of participants and Nurfitriyanti [11] which proved there was improvement of problem solving ability through the implementation of project based learning.

The observation has shown that process of attitude and behavior change has been done that were indicated by the willingness, identification and internalisation of nine values of anti corruption. The effectiveness of the anti corruption learning certainly can be continued to the effectiveness of its actualization, and that of habituation and hopely until in real work in BPKP.

According to the research, learning process using project based learning model has been undertaken delightly, interactively, usefully, and has supported the trainee's understanding of anti corruption values. However, there are some recommendations to improve the anti corruption learning subject in the future such as add anti corruption learning games, interactive quiz, examples and simulation of anti corruption cases. The recommendations are valuable in improving the planning of further research.

\section{REFERENCES}

[1] Abdulhak Ishak, "Konsep New Method Adult Learning", the $5^{\text {th }}$ Module, Diklat New Adult Learning, Kerjasama Departemen Pendidikan Luar Sekolah Fakultas Ilmu Pendidikan Universitas Pendidikan Indonesia dan Pusdiklatwas BPKP, Bandung, 2016

[2] Adib Muhammad Iyasy, M. Hafiz, M. Faisal Ghifari, M. Farhan Fauzan, M. Hardanu Hermawan, Rizky Amalia Putri, "Anti Korupsi, video clip-hasil project based learning kelompok 4, Kelas C, Latsar CPNS Gol II BPKP”, Pusdiklatwas BPKP, Bogor, 2018

[3] Fikriyah Musyriatul, Indrawati, Gani Agus Abdul, "Model Pembelajaran Berbasis Proyek (Project Based Learning) Disertai Mdeia Audio-Visual dalam Pembelajaran Fisikoa Di SMA Negeri 4, Jember', Jurnal Pembelajaran Fisika, Vol. 4 No.2, hal. 181-186, 2015.

[4] Idtesis, "Metode Penelitian Tindakan (Action Research)", idtesis.com, https://idtesis.com/metode-penelitian-tindakanaction-research1/ on March 16, 2018

[5] HP, Achmad, "Penelitian Tindakan Kolaboratif", Jakarta, 2000 (reference)

[6] Maulana Elen Yudha Shugara, Muhammad Juniardo, Mohammad Rifqi Hidayatullah, Muhammad Al Kahfi, Ricval Mawardi, Wita Rosmalia Siahaan, "Kelompok 1 Anti Korupsi, video clip-hasil project based learning kelompok 1, 
Kelas C, Latsar CPNS Gol II BPKP", Pusdiklatwas BPKP, Bogor, 2018

[7] M. Indra Arief Lubis, Muhammad Bayu Riyadi, Muhammad Faisal Izzudin Al-Qossam, Muhammad Habibi Pasi, Risan Adhitama, Riska Kurnia Maghfiroh, "Orkes Anti Korupsi, video clip-hasil project based learning kelompok 5 , Kelas C, Latsar CPNS Gol II BPKP", Pusdiklatwas BPKP, Bogor, 2018

[8] M Ishak Arofik, Mohammad Kenigi Harisandi, Muchammad Nurul Huda, Maraya Ghifara, Ribka Esti Prantiasih, Rizki Dita Ramadani, Muhamad Nafisya, "Anti Korupsi, video clip-hasil project based learning kelompok 2, Kelas C,Latsar CPNS Gol II BPKP", Pusdiklatwas BPKP, Bogor, 2018

[9] M. Sobri Qomarudin, Maria Endah Saraswati, Mauritzky Hasiholan Napitupulu, Muhamad Ridwanullah, Muhammad Khaidir Arief, Riris Purnalita, Saarah Khansaria Khairunnisa, "Korupsi Ini Membunuhmu, video clip-hasil project based learning kelompok 3, Kelas C,Latsar CPNS Gol II BPKP", Pusdiklatwas BPKP, Bogor, 2018

[10] Millennials Admin Rumah, "Siapa itu Generasi Millennial?", https://rumahmillennials.com/siapa-itugenerasi-millenials/\#.Wqcs2OhubIU, 2017

[11] Nurfitriyanti Maya, "Model Pembelajaran Project Based Learning Terhadap Kemampuan Pemecahan Masalah Matematika", Jurnal Formatif 6 (2): 149-160, ISSN: 2088$351 \mathrm{X}, 2016$

[12] Pratama Hendrik, and Prastyaningrum Ihtiari, "Pengaruh Model Pembelajaran Project Based Learning Berbantuan Media Pembelajaran Pembangkit Listrik Tenaga Mikrohidro Terhadap Kemampuan Berpikir Kritis", Jurnal Penelitian Fisika dan Aplikasinya (JPFA) Vol 6, No 2, ISSN: 20879946, e-ISSN: 2477-1775, http://journal.unesa.ac.id/index.php/jpfa, 2016

[13] Republik Indonesia, "Peraturan Lembaga Administrasi Negara Republik Indonesia Nomor 24 Tahun 2017 Tentang Pedoman Penyelenggaraan Pelatihan Dasar Calon Pegawai Negeri Sipil Golongan II (PerkaLan 24/2017)”. 2017

[14] Republik Indonesia, "Undang-Undang Nomor 5 Tahun 2014 tentang Aparatur Sipil Negara”, 2014

[15] Suharsono Agus, "Pengembangan Metode Pembelajaran Kompetensi Non Teknis Planning and Organizing Pegawai Direktorat Jenderal Pajak dengan Permainan Sundamanda", Simposium Pendidikan Tahun 2015, Jakarta, 2015

[16] Suryadi, Ace dan Pramudia, Joni Rahmat, "Model-model Pembelajaran Orang Dewasa, the 8th Module", Diklat New Adult Learning, Kerjasama Departemen Pendidikan Luar Sekolah Fakultas Ilmu Pendidikan Universitas Pendidikan Indonesia dan Pusdiklatwas BPKP, Bandung, 2016

[17] Tim Penyusun Modul KPK, "Anti Korupsi, Modul Pendidikan dan Pelatihan Prajabatan Golongan I/II dan III", Lembaga Administrasi Negara (LAN) RI, Jakarta, 2014

[18] Tim Penyusun Modul LAN, "Penelitian Tindakan Kelas, Modul Diklat Calon Widyaiswara", Lembaga Administrasi Negara RI, Jakarta, 2007 